\title{
sciendo
}

Research Article

(C) 2019 Victor F. Peretomode and Peter lkoya This is an open access article licensed under the Creative Commons Attribution-NonCommercial-NoDerivs License (http://creativecommons.org/licenses/by-nc-nd/3.0/).

\section{Mentorship: A Strategic Technique for Achieving Excellence, Manpower Development and Nation Building?}

\author{
Victor F. Peretomode \\ Peter Ikoya \\ Lecturer, \\ Department of Educational Management and Foundations, \\ Delta State University, Abraka, Nigeria
}

Doi: $10.2478 / \mathrm{mjss}-2019-0019$

\begin{abstract}
The aim of the paper is to address the possibility of using mentorship as a strategic technique for achieving academic excellence, manpower development and in over-coming challenges of nation building. The authors conducted an extensive review of relevant literature from studies based on quantitative, qualitative, mixed method research and position papers on mentoring. This was followed with an analysis, synthesis and integration of ideas arising therefrom. Thereafter, they developed a logical link between the three variables. The paper concludes that while mentorship may not be the panacea to attaining these variables, it no doubt can play a vital role in achieving academic excellence, manpower development and nation building and therefore it is a strategy worth investing time, effort and money in adopting a combination of appropriate models.
\end{abstract}

Keywords: Mentorship, Academic Excellence, Manpower Development, Nation Building

\section{Introduction}

The topic is a broad and an interesting question to address. It is also loaded with several very ubiquitous and illusive concepts. For example, concepts such as academic excellence, manpower development and nation-building are fluid as they have no generally accepted meaning in education and in the social sciences but are considered very important terms. While mentoring or mentorship has been long recognized in America and Europe as a very useful technique for improving on and in enriching the experiences, skills, knowledge and expertise of employees in organizations, including academic institutions, only recently that its usefulness is being realized in higher institutions of learning in Nigeria.

In order to put this theoretical and positional paper in a proper and explicit perspective, we first attempted to explain the basic terms, mentorship and its types, academic excellence and nation building. Thereafter, attempt was made to explain the importance and the nexus between mentorship and academic excellence, manpower development and nation building.

Mentorship is a noun and a relationship concept. A mentor is a more experienced, knowledgeable and trusted person who gives a younger or less experienced person help and advice over a period of time. This relationship in which the more experienced or knowledgeable person helps to guide a less experienced or less knowledgeable person is called mentorship and the process involved is referred to as mentoring. Mentoring has also been consedered a personal enhancement strategy through which one person facilitates the development of another by sharing known resources, ideas, learning, expertise, values, skills, perspectives, attitudes, and proficiencies 
and professional competence. It allows the "learner to build skills and knowledge while attaining goals for carrier development" (Klinge, 2015, Defense Logistics Agency, 2018).

The mentor may be older or younger than the person being mentored (the mentee or protégé). As Wikipedia (2017) rightly pointed out, mentorship is "a learning and development partnership between someone with vast or in-depth experience and knowledge (the mentor) and someone who wants to learn, build skills and knowledge while attaining his goals. The person who wants to learn could be a male (mentee) or a female (protégé)" (Bozeman \& Feeney, 2007).

The word "mentor" is derived from Greek mythology when Odysseus, king of Ithaca, entrusted the care of his son to his friend, Mentor, to serve as a guide and teacher, a man who could raise his son, Telemachus, just as he would if he were there; If he had not gone to fight in the ten years Trojan War (Carey and Weissman, 2010). Since then, the term has evolved and the practice has become acceptable and popular. It has also come to be broadly categorized into two, namely formal and informal mentorship.

A formal mentorship is one in which the mentor - mentee relationship is organizationally structured. The management of the organization is responsible for deliberately selecting and pairing the mentee and the mentor with the goal of assisting the mentee "grow and develop specific competencies" (Murray, 2001: p. xiii). In an informal mentorship, on the other hand, it is the employee (the mentee or protégé) who requires training that selects the mentor - the person with more expertise, experience, knowledge and advice he wants to share with or understudy. Informal mentoring is, therefore, a "little or loosely" structured mentoring relationship between the mentor and mentee. When both formal and informal mentorship are combined, they bring more benefits and value to "everyone involved; the mentors, mentees and the organization" (www.fukecacge,drivetheweb.com) retrieved 03/06/2018.

Mentoring, it should be noted, is more than just giving advice on how to work more effectively or handle a specific problem. It involves the mentor taking personal interest in seeing that a mentee developed the right talent, skills, values, attitudes, expertise and knowledge needed to succeed, to have a successful career and contribute as much as possible to the organization, society and the nation.

Gosh \& Reid Jnr (2013) and Power (2017) pointed to the importance of mentoring programme when they opined that such programmes enable the organization to capitalize on its greatest resource - the employees - by strategically developing their talent, improving their productivity and quality of their services at reduced cost (Murray, 2001). It also shows that management cares and it's willing to invest the time and resource necessary to help employees succeed in their careers. The result is that employees have high job satisfaction, higher commitment to organization and low turnover of employees and high level loyalty to the organization.

\section{Qualities of a Good Mentor}

For a mentor to achieve his goals he must possess certain key qualities;

i. Ability and willness to clearly communicate his values, skills, knowledge and expertise.

ii. Be prepared always for each mentoring session.

iii. Be prepared to show faith in his mentee's abilities and willingness to learn.

iv. Should be available, approachable, flexible, and be an active listener.

v. Should be trusted, honest, candid and straightforward whenever the mentee asks questions.

vi. Should provide guidance and constructive feedback to the mentee.

vii. Always be ready to follow up to find the answers to questions asked by his mentee that he does not know.

viii. Be objective and fair in the mentor - mentee relationship.

ix. There should be high degree of openness; there should be no hidden agenda or ulterior motives involved in the relationship.

x. He should be able to show genuine compassion (Demers, 2017).

xi. He should be able to celebrate the mentee whenever he achieves a task (Lovetto, 2018)

xii. He should be willing to step out of his comfort zone and be dedicated to others' successes 
xiii. The mentor should be able to allow the partnership to focus on the needs of the mentee.

\section{Mentoring Techniques}

There are a number of mentoring techniques. Some of them have been summarized in the table below.

\begin{tabular}{|c|c|c|}
\hline $\mathbf{S} / \mathbf{N}$ & Types & Description of Mentoring Technique \\
\hline 1 & $\begin{array}{l}\text { One-On-One } \\
\text { Mentoring (Dyads) }\end{array}$ & $\begin{array}{l}\text { As the name suggests, this is a relationship process which involves two people. } \\
\text { It allows one individual (the mentor) to share his experience, knowledge, skills } \\
\text { and expertise with another individual (the mentee). }\end{array}$ \\
\hline 2 & Triad Mentoring & $\begin{array}{l}\text { This involves three people; a primary mentor who could be a senior staff } \\
\text { mentoring two mentees of equivalent status or one senior staff mentoring one } \\
\text { mid-level, and one junior person. }\end{array}$ \\
\hline 3 & Group Mentoring & $\begin{array}{l}\text { A single mentor meets and works with multiple mentees (four to six) as a group } \\
\text { at a time to share ideas, experience and knowledge. }\end{array}$ \\
\hline 4 & \begin{tabular}{|l|} 
Team Mentoring $/$ \\
Multiple Mentoring
\end{tabular} & $\begin{array}{l}\text { This is a situation where a mentee works with multiple mentors or several } \\
\text { mentors work with several mentees who meet as a team. }\end{array}$ \\
\hline 5 & $\begin{array}{l}\text { Peer Mentoring } \\
\text { (Peer-to-peer } \\
\text { mentoring) }\end{array}$ & $\begin{array}{l}\text { This is a form of mentorship in which members with equal ranks or similar level } \\
\text { of responsibility developed supportive networks to improve the effectiveness of } \\
\text { one or the other. }\end{array}$ \\
\hline 6 & Distance Mentoring & $\begin{array}{l}\text { This is a mentoring relationship in which the two parties or groups are at different } \\
\text { locations; e.g in separate campuses of a University. }\end{array}$ \\
\hline 7 & E-mentoring & $\begin{array}{l}\text { One mentor works with a single mentee or protégé at a time via the internet, e.g } \\
\text { through skype, email, facetime. This type of mentoring is extremely helpful for } \\
\text { institutions that have multiple branches or campuses. }\end{array}$ \\
\hline 8 & Reverse Mentoring & $\begin{array}{l}\text { This is a situation where a younger overall less experienced person but more } \\
\text { talented and knowledgeable in a particular area (e.g. ICT) works with an older or } \\
\text { senior colleague as the mentee. }\end{array}$ \\
\hline 9 & $\begin{array}{l}\text { Reciprocal } \\
\text { Mentoring }\end{array}$ & $\begin{array}{l}\text { This is a relationship where neither party is designated "mentor". Each is a } \\
\text { confidante and a resource to the other. Each serves as a sounding board for } \\
\text { ideas and a reality check for plans. }\end{array}$ \\
\hline 10 & $\begin{array}{l}\text { Employee - Al } \\
\text { Mentoring }\end{array}$ & $\begin{array}{l}\text { Alumni can be viewed as corporate ambassadors and big organization realizing } \\
\text { the potential inherent do link employees and alumi. }\end{array}$ \\
\hline
\end{tabular}

Note: There is no one mentorship model that fits all. A combination of models may work best for an organization.

\section{Theoretical Framework}

There are several theories, approaches and models of mentoring. These include the constructive developmental approach, the apparatus of social network model, the transformation into developmental network approach (Krams, 2001), the adult learning and self-directed learning theory (Knowles et al., 1998) and the action-reflection model (Handal and Lauvas, 1983, 1990) etc. Among all these, there is no one that is generally accepted because of the persistent problems in the development of mentoring theory (Bozeman and Feeney, 2007). This paper is based on a combination of ideas from the action - reflection model and the adult learning theory.

The action - reflection model is a humanistic and dialetic model developed by Handal and Lauvas $(1983,1990)$ and it is generally accepted in certain countries such as Norway. The focus of mentoring is "on helping the mentee become better at understanding the theory behind the practice and the goal is to create awareness about core values, experience and knowledge that direct our actions" (https://en.wikibooks.org>theories.retrieved 10/02/2019). It is not surprising therefore that the term "practice theory" is "an important term in the action-reflective model. The model emphasizes "planned, formalized mentor-mentee conferences" rather than informal mentoring.

The theory of andragogy, on the other hand considers mentoring as the "art and science of helping adults learn" (Merriam, 2001, p.5). It argues that the task of the mentor is to facilitate learning, create an educational programme and setting in which adult students can develop their 
latent self-directed learning skills" (Brookfield 1986:92). These authors believe that as the mentee is helped to learn he will grow to continue self-directed learning - learning without the mentor - to imbibe the values, the right attitude, skills, acquire the relevant knowledge, experiences and become more effective in society. All these positive attributes can bring about achieving set goals of excellence, manpower development and nation building.

This conceptualization has been illustrated in Figure 1.

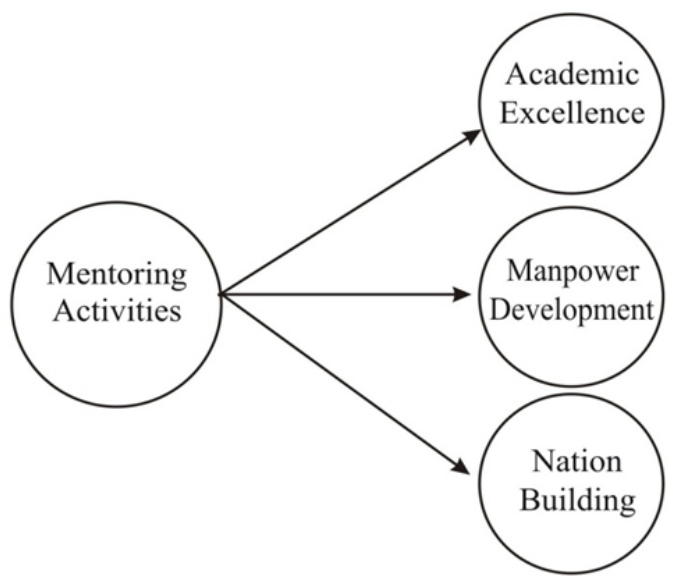

Figure 1: Conceptual Model illustrating the nexus between mentoring activities and academic excellence, manpower development and nation building.

\section{Methodology}

A number of previous studies have conducted quantitative researches to explore the empirical relationship between mentoring and academic achievement but not manpower development and nation building either quantitatively or qualitatively or theoretically. In order to adequately address this research topic, which is our goal, we decided to conduct an extensive review of the relevant literature from quantitative, qualitative, mixed research methods and positional papers. We analyzed, synthesized and integrated the ideas therefrom and thereafter developed a logical link between mentoring as an independent valuable and academic excellence, manpower development and nation building as dependent variables.

\section{Mentorship and Academic Excellence}

Academic excellence is a ubiquitous and an elusive quality as the word beauty. It is used in many different ways that it can almost be meaningless but one thing is clear, like beauty, if you see one you recognize it. While academic excellence has been defined as "the demonstrated ability to perform, achieve and /or excel in scholastic activities, and has been identified with achieving high grades and superior performance" (Csufresno.edu 2017:01:23), it is more than just making grades (Wikipedia 2017). It is better considered as superior performance cum the maximum development of the intellectual capacities and skills of the individual in service to humanity.

While mentorship may not be a panacea to academic excellence, these authors believe that it is one sure road to achieving academic excellence, obtaining high scores and improving on the intellectual capacity of an individual or mentee. For example, in making a world class research Universities, Altbach \& Salmi (2011), expressed the view that the modern university is the ideal space for the ecosystem of scholars to search for new ideas in a spirit of free inquiry (p.xiii) and mentorship plays a significant role in this.

Since mentoring is a way by which experience, knowledge, expertise, skills and values can be 
shared, it is no doubt an effective form of training in which the mentee is getting personal and professional development. Mentoring can, therefore, be considered a strategic technique for building and sustaining scholars in research universities that provide advanced education for the academic profession, policy makers and public and private sector professionals involved in the complex globalized economies of the $21^{\text {st }}$ century. Mentoring is surely an effective way of passing on experience and developing the neophyte and even the old who may wish to develop skills and expertise in certain specific areas. The works of Cox (1997) and Crisp and Cruz (2009) have shown that mentoring enhances academic excellence and there is a positive relationship between proper mentoring and high academic achievement at all levels of education including tertiary education level.

Further, results of a number of empirical/ quantitative studies have shown that mentorship significantly and positively affected and improved the academic performance, experience and productivity of students and thus enhanced academic excellence (Bland et al., 2009; Cho et al., 2011; Fleming et al., 2012; Shcker, and Palmer, 1993; Nagda et al., 1998; Bordes - Edgar et al., 2011; Camphell and Compbell, 1997; Thompson \& Kelly - Vaance, 2001; Karanja \& Gukingu, 2014; Pfund, 2016). More specifically, Campbell and Campbell's quantitative study showed that mentored students obtained better academic achievement than those who did not participate in the mentoring program. Similarly, Thompson and Kelly-Vaance found that mentored boys made significantly higher academic gains than non mentored boys. Further, Bordes - Edgar et al., pointed out that mentoring has been found to improve, directly or indirectly, GPA and persistence of college students.

\section{Manpower Development}

Manpower development, now commonly referred to as human resource development (hrd), is an ongoing process that analyzes, forecasts and projects an organization's future manpower requirements. Manpower development is an indispensable ingredient in the growth of a nation's economy. An important element in manpower management is manpower planning also referred to as human resource planning (hrp). HRP consists of putting the right number (quantity) of people, right kind (quality) of people, the right mix of people (the right quantity and quality) at the right place at the right time, doing the right things for which they are suited for the achievement of goals of the organization. The role Human Resource Planning plays in the industrialization of a nation cannot be overemphasized (managementstudyguide.com.2017:01:15).

Manpower refers to the total supply of humans (personnel - men and women) available or engaged for a specific job or task. Whether there is manpower surplus or manpower deficit, one thing that is clear in an organization is that the available personnel may be skilled or unskilled. They may not be fully developed as workers and therefore over the course of time there is the need for an organization to train or re-train them to perform specific tasks. This training required of the personnel can also be referred to as manpower development (Ekpo, 1989) or staff renewal. Mentoring, is an important technique for developing employees within an organization. It is little wonder then that manpower development has been considered as "a Human Capital function which is responsible for developing the skills, knowledge, attitudes and competence of the organization's most important asset, its people, in order to meet current and future organizational requirements and goals" (www.adma.opco.com, 12/02/2017).

Some methods of manpower development in organizations include the following: coaching, job rotation and job enlargement, in-house training, in-service training, workshop/committee meetings, vestibule training, apprenticeship method (Yalokwu, 2000; Nongo, 2005; Lawal, 2006). Mentorship, if incorporated in these techniques enhances and enriches the quality of learning experience, attitudes, skills, expertise and knowledge required of and acquired by the worker. Lankau and Scandura (2002) also confirmed that organizations are using mentoring programmes to enhance their human resources and organizational learning. 


\section{Nation Building}

A nation is a group of people with shared history, traditions, and culture, sometimes religion and usually language. Nation- Building is the building of a shared or a common national identity (Stephenson, 2005). The purpose of creating this unification or common identity is to establish a politically stable and viable stable state in the long run (Wikipedia, 2017). Thus, in Nation - building, there are persons who are doing the building intentionally and the older and more experienced persons with the desirable values, norms and culture play a major role in transmitting these customs and structures to the young generations to imbibe and carry on the growth and development and sustenance of the nation building. Reid (2018) pointed out that mentoring provides a higher form of leadership which is a remarkable means to develop future generations of leaders who could be instrumental in establishing a strong nation.

\section{The Role of Mentorship in Academic Excellence, Manpower Development and Nation Building}

It needs to be stated from this point in the discuss that mentoring may not be the panacea to all three dependent variables. However, it could be argued that mentoring is a very crucial and promising strategy for the pursuit of and in finding solutions to the problems of academic excellence, employee development and nation building.

Excellence, including academic excellence, is never an accident. As Rodriguez (2015) noted, "it is the result of high intention, sincere effort, intelligent direction and skillful execution". Mentoring is vital in achieving academic excellence because it helps students to proactively navigate learning in higher education by role - modeling effective study habits, offering supportive and collaborative environments for good teaching, learning, research, innovation and extension services. It also helps students and amateur researchers and less experienced and less knowledgeable staff to develop into more confident, self-directed independent learners and researchers. Here, mentoring serves to promote academic excellence and serves as a useful strategy for manpower development. It is, therefore, not surprising that Jekielek and Moore (2002) expressed the view "that interest in mentoring is at all times high" (p.1).

Jekielek and Moore (2002) conducted a study on mentoring as a promising strategy for youth development and they asserted that because academic achievement is a key predictor of socioeconomic status, many mentoring programmes have led to improving the academic and congnitive skills and experiences of young people and other learners. Overall, youth participating in mentoring relationship experience positive academic returns through better attendance, better chance of going on to higher education, better attitudes toward school and it improves grades. They concluded that young people who perceived high quality relationships with their mentors experienced the best results.

On manpower development and nation building, it has been argued that a diverse workforce is required to stimulate innovation, cultivate creativity and steer business strategies. Mentoring, especially diversity mentoring, empowers a diverse range of employees to share their opinions, ideas, knowledge, and experience on a level playing field. Further, mentoring creates an environment of trust, belonging, understanding, support and encouragement for a diverse workforce. Mentoring, therefore, not only helps organizations develop and retain diverse talents, it also helps build a robust community of diverse talents for the future and helps in bonding diverse people for nation-building (http://chronus.com/how-to-use-mentoring-in-your-workplace. retrieved 12/02/2018).

\section{Conclusion}

Mentorship is an important concept and technique. Although it might not serve as a panacea, a solution to all, it is no doubt a very promising technique for achieving academic excellence, manpower development and nation building. If the results of the numerous empirical studies cited above are anything to go by, it could be conveniently stated that the benefits of mentorship are 
such that it is worth investing, time, effort and money at all levels of a nation.

Mentoring is vital for recruitment and retention of qualified employees and guiding neophites and assisting them in their career development. It is also important for leadership development and bonding among persons of diverse cultures. In a time such as ours in Nigeria characterized by economic crunch, ethnicism, falling quality of education and poor quality of our University graduates, calls for restructuring of the nation, and the increasing shortage of talented, experienced and knowledable and distinguished researchers in our Universities, mentoring and the sustenance of mentoring relationships will no doubt go a long way to finding solutions to the problems and challenges that we face in organizations and in the country, Nigeria, today.

\section{References}

Altbach, Phillip G. \& Salmi, Jamil (eds) (2011). The Road to Academic Excellence: The making of World-Class Research Universities. Washington, D.C.: The World Bank.

Berk, R.A. (2010). Where is the Chemistry in mentor-mentee academic relationships? Trying speed mentoring: International Journal of Mentoring and Coaching, 8, 85-89.

Bland, C., Taylor, A., \& Shollen, S. (2009). Faculty Success through mentoring: a guide for mentors, mentees, and leaders. Lanham, M.D: Rowman \& Little field Pulishers, Inc.

Bordes - Edgar, V., Arredondo, P., Kurpius, S.R. and Rund, J. (2011). A longtitudinal analysis of Latina's Students academic persistence. Journal of Hispanic Higher Education. 10, 358-368.

Bozeman, B. \& Feeney, M.K. (October, 2007): "Toward a useful theory of mentoring. A conceptual analysis and critique". Administration and Society. 39 (6), 719-739.

Bozeman, B. \& Freeney, M.K. (2010). Mentor Matching: a goodness of fit model. Administration and Society 40(5),. 465-482.

Brookfield, S. (1986). Understanding and facilitating adult learning. San Francisco: Jossey - Bass.

Brookfield, S. (1995). Adult learning: An overview. In A Tuinjman (Ed), International Encyclopedia of education (Electronic Version) Oxford: Pergamon Press.

Campbell, T \& Campbell, D.E (1997). Faculty /Student mentor programme: effects on academic performance and retention. Research in Higher Education. 38, 727-742.

Carey, E.C. \& Weissman, D.E (2010). Understanding and finding mentorship: a review for junior faculty. Journal of Palliative Medicine. 13 (11), 137-1379.

Carson, N \& Birkelan, A. (2009). Veeildning for forskolelaerere Kristiansand; Hogskoleforlaget.

Cho, C., Ramanan, R. \& Feldman, M. (2011). Defining the ideal qualities of mentors. Am J. Med. 124, 453 458.

Cox, M.D. (1997). Walking the right rope: The role of mentoring in developing educators as professionals in Mullen, C.A. In M.D. Cox, C.K. Boettcher, \& D.S. Adoue (Eds) Breaking the circle of one: Redefining mentorship in the lives and writings of educators. NY: Peter Lang.

Crisp, G. \& Cruz, I. (2009). Mentoring College Students: A critical review of the literature between 1990 and 2007: Research in Higher Education 50,525 - 545

Daloz, L.A. (1990). Effective Teaching and Mentoring. San Franciso: Jossey Bass. P.20.

Defense Logistics Agency (2018) DLA Land and Maritime.

Retrieved from http://www.dlami/landand/maritime/people-and-culture/mentoringprograms/accessed/08/06/2018

DeMers, J. (2014) 7 Key Qualities of an effective mentor. https://www.in.com>jayson-demers >>.. Retrieved $30 / 12 / 2018$.

Fleming, M., Burnham, E. \& Huskins, W. (2012a). Mentoring translational science investigatory. J.Am. Med. Assoc. 308, 1981-1982.

Fountain, D.L. \& Arbreton, A. (1999). The cost of mentoring". In J. Grossman, (Ed.), Contemporary Issues in Mentoring. (pp. 48-65) Philadelphia: Public/Private Ventures.

Gagen, L. and Bowie, S. (2005). Effective mentoring: a case for training mentors for novice teachers. Journal of Physical Education, Recreation and Dance. 76,(7), 40-45.

Gosh, R. \& Reid. Jr., T.G. (2013). Career benefits associate with mentoring for mentors: A meta - analysis. Journal of Vocational Behaviour (August) 83 (1): 106-116.

Haggard, D.L., Dougherty, T.W., Turban, D.B. \& Wilbanks, J. E. (2011). Who is a mentor? A review of evolving definition and implications for research. Journal of Management, 37(1), 280-304.

Handal, G. \& Lauvas, P. (1983) Pa egne vilka: en strategi for veiledning med laerere. Oslo: Cappelen.

Handal, G. \& Lauvas, P. (1990). Veiledning og praktisk yrkesteori, Oslo: Cappelen.

Jekielek, S.M \& Moore, K.A. (2002). Mentoring: A promising strategy for Youth Development. Child Trends. Retrieved from http://www.childtrends.org. Accessed 04/04/18. 
Karanja, B.W. and Gukingu, J.M. (2014). Effect of mentorship programmes on the performance of students in secondary schools in Mbooni East District, Makueni Country - Kenya. Meditarranean Journal of Social Sciences. 5,5, 167-175.

Klinge, M.C (July 6, 2015). A conceptual framework for mentoring in a learning organization. Adult Learning journals. Sagepub.com.https://doi.org/10.1177/10.1177/104515

Lankau, M.J., \& Scandura, T.A. (2002). An investigation of personal learning in mentorship relationships: Content, antecedents, and consequences. Academy of management Journal, 45, 779 - 790.

Lovetto, P. (December, 2018) 8 qualities of a good mentor. Management Coperate Mentoring Tips: 7 Habit of highly successful mentors and mentee https://www.thebalancecareers.com Retrieved 30/12/18

Murray, M. (2001). Beyond the myths and magic of mentoring how to facilitate an effective mentoring process, New and Revised Edition. San Francisco: Jossey-Bass.

Nagda, B.A., Gregerman, S. Jonides, J., Von Hippel, W., \& Lerner, J. (1988). Undergraduate Student - faculty research partnerships affect student retention. The Review of Higher Education 22, 55-22.

Nick, Jan M et al (2012). Best Practices in Academic Mentoring: A Model for Excellence. Nursing Research and Practice, Volume 2012, Article ID 937906, 9 Pages. http://dx.dol.org/10.1155/2012/937906.

Odiome, G.S. (1985). Mentoring - An American Management Innovation. Personal Administration. (30): 63-65

Parsloe, E. \& Wray, M.J. (2000). Coaching and mentoring: practical methods to improve learning. London, Kogan page

Pfund, C. (2016). Studying the role and impact of mentoring on undergraduate research experience. Paper commissioned for the committee on strengthening research experiences for undergraduate STEM students. National Academics of Sciences, Teaching, Engineering and Medicine Avaliable: http://nas.edu/STEM_undergraduate_Research_Mentoring. Accessed 30/07/18.

Power, R. (2017). Three Reasons your company needs a mentoring programme. Retrieved from http://www.mc.com Accessed 24/05/18.

Ragins, B. \& Kram, K. (2007). The handbook of mentoring at work: Theory, Research and Practice. Los Angeles: Sage publications.

Reid, L. Alvin (2018): A guide to informal mentoring. Retrieved from http:// www.twitter.com, alvinreid.com Accessed 03/06/2018

Sliker, E.K \& Palmer, D.J. (1993). Mentoring at-risk high school students: evaluation of school-based program. School Counselor. 40, 327-334.

Smith, J.A. \& Zsohar, H. (2007) Essentials of neophyte mentorship in relation to the faculty shortage. Journal of Nursing Education. 46,(4),. 184-186.

Sorcinelli, M.D. \&Yun, J. (2007). From mentor to mentoring networks: mentoring in the new academy. Change, $39,6, .58-61$.

Thomson, L and Kelly-Vance (2001). The impact of mentoring on the academic achievement of at risk youth children. Children and Youth Services Review. 23, (3), 227-242. 